\title{
Targeting platelet-derived growth factor as a therapeutic approach in pulmonary fibrosis
}

\author{
Yasuhiko Nishioka, Momoyo Azuma, Masami Kishi, and Yoshinori Aono \\ Department of Respiratory Medicine and Rheumatology, Institute of Health Biosciences, the University \\ of Tokushima Graduate School, Tokushima, Japan
}

\begin{abstract}
Idiopathic pulmonary fibrosis (IPF) is a progressive and lethal lung disease characterized by the proliferation of fibroblasts and deposition of extracellular matrix. Since the prognosis of IPF is still poor, novel therapeutic modalities are strongly required. For this reason, to find molecular target for therapy of IPF is of much importance. The recent understanding of pathogenesis in IPF indicates the critical role of alveolar epithelial type II cells (AECII) and fibroblasts. Although the detailed mechanisms involved in IPF is still unclear, various profibrotic mediators which are produced by the injured AECII are thought to play a role in the progression of pulmonary fibrosis via stimulating fibroblasts. Among them, platelet-derived growth factor (PDGF) is one of critical growth factors by stimulating the proliferation and migration of fibroblasts. In this review, we discuss the role of PDGF in pulmonary fibrosis and the possibility as a therapeutic target for IPF. J. Med. Invest. 60 : 175-183, August, 2013
\end{abstract}

Keywords : idiopathic pulmonary fibrosis, platelet-derived growth factor, tyrosine kinase, fibroblast

\section{INTRODUCTION}

Idiopathic pulmonary fibrosis (IPF)/usual interstitial pneumonia (UIP) is a progressive and lethal lung disease characterized by the proliferation of fibroblasts and deposition of extracellular matrix (ECM) including fibrillar collagens, fibronectin, elastic fibers and proteoglycans $(1,2)$. While corticosteroids and other immunosuppressants have been used for the treatment of patients with IPF, the response rate to these agents was low, and the fiveyear survival rate of IPF is less than $50 \%(3,4)$. Recent guidelines for IPF describe that no effective pharmacological therapy has been developed so far

Received for publication July 2, 2013 ; accepted August 26, 2013.

Address correspondence and reprint requests to Yasuhiko Nishioka, M.D., Ph.D., Department of Respiratory Medicine and Rheumatology, Institute of Health Biosciences, the University of Tokushima Graduate School, Tokushima 770-8503, Japan and Fax : +81-88-633-2134.
(5). For this reason, novel therapeutic modalities are still of strong interest.

However, the molecular pathogenesis involved in pulmonary fibrosis is not fully investigated. In addition, from the therapeutic point of view, we do not have the right answer to the question which is best target to treat pulmonary fibrosis.

More recently, Nintedanib (BIBF1120) which is the multikinase inhibitor of three receptors for platelet-derived growth factor (PDGF), fibroblast growth factor (FGF) and vascular endothelial growth factor (VEGF) have been shown the inhibitory activity for the progression of IPF in TOMORROW phase II clinical trial (6). Based on this trial, PDGF is believed to be one of promising targets for therapy of IPF. In this review, we consider the update molecular pathogenesis in IPF, and discuss the possibility of targeting PDGF as a therapeutic approach of IPF. 


\section{MOLECULAR PATHOGENESIS IN IPF}

The molecular mechanisms involved in the progression of IPF are still not fully understood, whereas the alveolar epithelial type II cells (AECII) and fibroblasts are thought to be main players (Figure 1). As the first event, AECII injury is caused by endoplasmic reticulum (ER) stress, lysosomal stress, and mitochondrial and DNA damage $(7,8)$. AECII are known to have genetic predisposition like gene mutations of surfactant protein $\mathrm{C}$ or $\mathrm{A} 2$, telomerase and MUC5B in subjects with familial pulmonary fibrosis, which lead to be susceptible for the second stimuli such as cigarette smoking or viral infection. After the second stimuli, the injured AECs have the tendency to be apoptotic. The link of injured AECII and fibrosis is not fully understood, but it was reported that those cells could produce the fibrotic mediators. Among profibrotic mediators, transforming growth factor (TGF) $-\beta$ and PDGF are thought to play a critical role in the fibrogenesis of the lungs.

\section{PDGF AND PDGF RECEPTORS}

PDGF is a homo- or heterodimeric molecule with a molecular weight of $30 \mathrm{kDa}$ (7). PDGF genes are consisted of four different genes including PDGF$\mathrm{A},-\mathrm{B},-\mathrm{C}$ and $-\mathrm{D}$, which are located on chromosomes 7, 22, 4 and 11, respectively $(9,10)$. There are two types of PDGF receptors (PDGFRs), $\alpha$ and $\beta$, which have a molecular weight of $170-180 \mathrm{kDa}$, and composed of homo- or heterodimers. The possible PDGF-PDGFR interactions are multiple and complex in in vitro study as shown in figure 2 (11). However, the in vivo study showed the binding of PDGF-AA or -CC to PDGFR- $\alpha$, and PDGF-BB to PDGFR- $\beta$ (11). PDGF dimers can bind their receptors and induce the dimerization of PDGFR, which allow their autophosphorylation of tyrosine residues in trans between two receptors (9). After the autophosphorylation, activated PDGFR can coupled with various signal transduction molecules such as RasMAPK through Grb2 and Shc adaptor proteins, and phosphatidyl inositol-3 kinase and phospholipase C- $\gamma$. PDGFR interacts with integrins and induced cell migration through activation focal adhesion kinase (FAK).

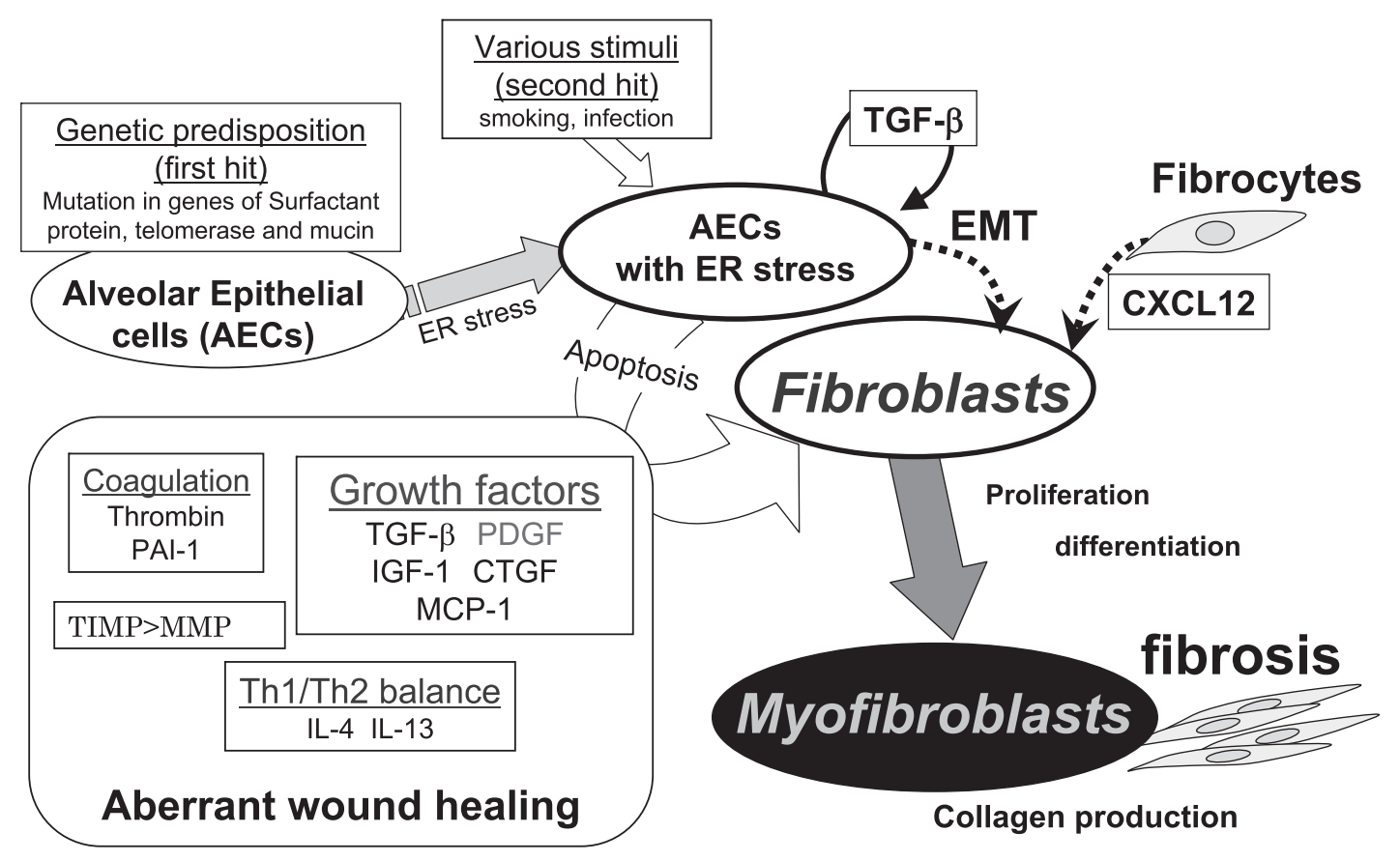

Figure 1 Molecular pathogensis of IPF

Alveolar epithelia cells (AECs) are known to have genetic predisposition like gene mutations of surfactant protein C or A2, telomerase and MUC5B in subjects with familial pulmonary fibrosis, which induce endoplasmic reticulum (ER) stress and lead to be susceptible for the second stimuli such as cigarette smoking or viral infection. After the second stimuli, the injured AECs have the tendency to be apoptotic and produce the profibrotic mediators. Although the link of injured AECs and fibrosis is not fully understood, among profibrotic mediators, transforming growth factor (TGF) $-\beta$ and PDGF are thought to play a critical role in the fibrogenesis of the lungs, which induce the proliferation and differentiation to myofibroblasts of fibroblasts. 


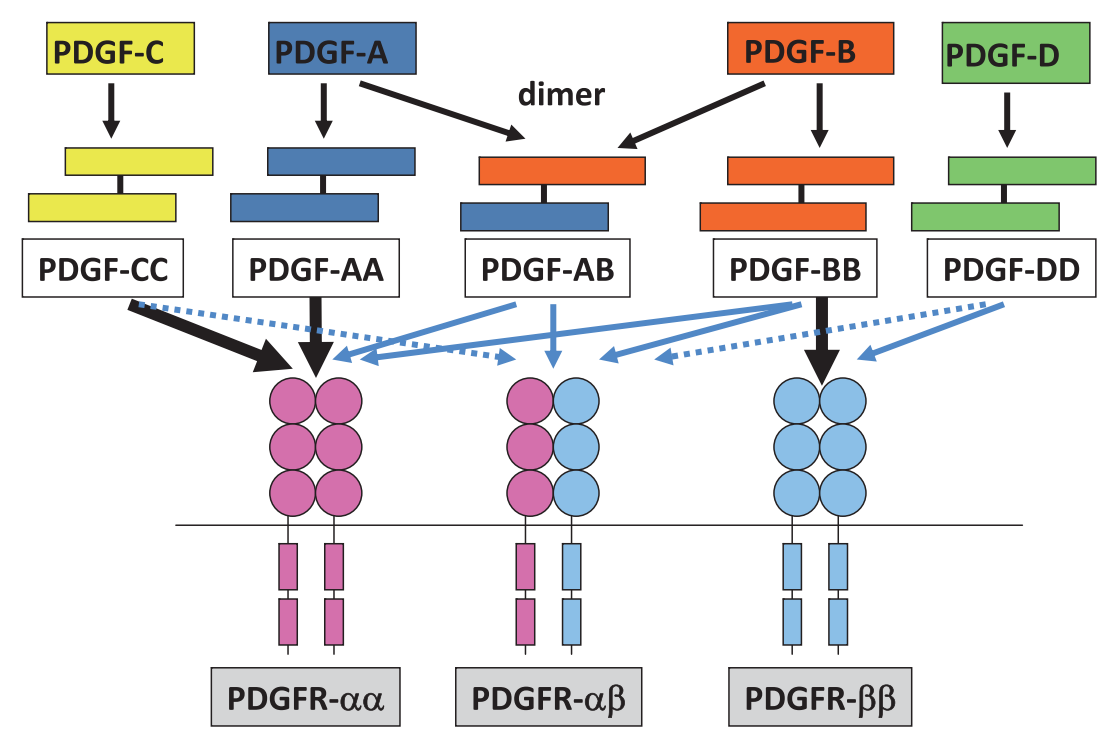

Figure 2 PDGF-PDGFR system

The four PDGF proteins make a homo- or hetero-dimers and bind to PDGF receptors. The black bold arrow indicates the bindings which are confirmed in vivo. The blue arrows indicate the binding in cell culture. The hatched arrows indicate weak interactions or conflicting results.

\section{EXPRESSION OF PDGFS AND PDGFRS}

PDGFs are expressed in many types of cells including fibroblasts, vascular endothelial cells, macrophages as well as platelets/megakaryocytes (9). It is known that the expression of PDGFs is up-regulated by various inflammatory cytokines and growth factors including TGF- $\beta$ and PDGF themselves. PDGFRs are also expressed in various cells although the classical targets of PDGF are fibroblasts and smooth muscle cells. The expression of PDGFRs is also induced by various stimuli. In contrast to PDGFs, expression of PDGFR in some cells is limited to PDGFR- $\alpha$ or PDGFR- $\beta$, but not both.

\section{BIOLOGICAL ACTIVITIES THROUGH PDGF/ PDGFR}

PDGF is known to be a major mitogen for mesenchymal cells. PDGF is a strongest stimulus of proliferation of fibroblasts (9). In addition, binding of PDGF to their receptors induces $\mathrm{Ca}^{2+}$ influx and rearrangement of the cytoskeleton involving changes in the arrangement of actin stress fibers. In terms of these responses, PDGF also stimulates the migration of various cells.

\section{LUNG DEVELOPMENT AND PDGFS/ PDGFRS}

The knock-out mice of the PDGF-A gene showed the homozygous lethal with two different restriction points, one prenatally and one postnatally (12). Postnatally surviving PDGF-A-deficient mice develop lung emphysema secondary due to the loss of alveolar myofibroblasts which has PDGFR- $\alpha$. On the other hand, the PDGFR- $\alpha$ null mice showed the cranial malformations and deficiency of myotome formation (13). Mice deficient for PDGF-B revealed renal, cardiovascular and hematological abnormalities (14). Similarly, PDGFR- $\beta$ mutant mice exhibited abnormal kidney development and hematological disorders, but cardiovascular abnormality was not detected (15). In summary, PDGF-A/PDGFR- $\alpha$ pathway plays a role in the secondary septation process, since PDGFR- $\alpha$-expressing cells locate in the alveolar entry ring and have characteristics of myofibroblasts (16).

\section{PDGF AND PULMONARY FIBROSIS}

It is known that PDGF is one of the growth factors which play a role in the pathogenesis of pulmonary fibrosis $(9,11)$. In the animal models, bleomycininduced pulmonary fibrosis has been used for the analysis of molecular pathogenesis in mice or rats. 
Maeda et al. reported that expression of the PDGFA gene increased in bleomycin-induced pulmonary fibrosis models in mice using semi-quantitative reverse transcriptase-polymerase chain reaction (RT-PCR) (17). Walsh et al. have examined the bronchoalveolar lavage fluid of rats treated with a bleomycin, and could find the $38-40 \mathrm{kDa}$ and 29 $\mathrm{kDa}$ peptides, which were detected with anti-PDGF$\mathrm{BB}$ and anti-PDGF-AA antibodies, respectively, showed the growth-promoting activity of lung fibroblasts (18). The growth-promoting activity was neutralized $64 \%$ by anti-PDGF-BB antibody and $15 \%$ by anti-PDGF-AA antibody. In contrast, Zhuo et al. showed that PDGF-C gene, but not PDGF-A, B and $\mathrm{D}$, was induced in the lungs of mice treated with bleomycin by Northern blot analysis (19). Shimizu et al. reported that both PDGF-A and -B was induced and elevated in bleomycin-treated lungs of mice at the levels of both mRNA and protein (20). Adoptive transfer of an adenovirus expressing the PDGF-B gene into the lung induced severe fibrosis in mice (21). From these reports, the expression of PDGF isoforms could be enhanced in fibrogenesis of the lungs, but the details are required to be further analyzed.

On the other hand, enhanced expression of PDGF in the epithelial cells and alveolar macrophages in lungs of patients with IPF has been reported (22, 23). However, the mechanisms involved in the enhanced expression and action of PDGF in the fibrotic lung are poorly understood. Recently, Gochuico et $a l$. has examined the growth factors in alveolar lining fluids of patients with rheumatoid arthritis complicated with pulmonary fibrosis, and reported that PDGF-AB and -BB, but not TGF- $\beta$ and PDGF-AA, was associated with the progressive stage of pulmonary fibrosis (24), indicating the importance of PDGF-B in the fibrogenesis of the lungs.

\section{ANTIFIBROTIC EFFECTS OF TARGETING PDGF/PDGFR SIGNALING PATHWAY IN ANIMAL MODELS}

Several evidences described above suggest the targeting PDGF/PDGFR signaling pathway might lead to show the therapeutic effects against pulmonary fibrosis. This hypothesis has been investigated using animal models of pulmonary fibrosis with specific inhibitors for PDGFR.

Rice et al. firstly reported that AG1296, the inhibitor for the tyrosine kinase of PDGFR, prevented pulmonary fibrosis induced by vanadium pentoxide $\left(\mathrm{V}_{2} \mathrm{O}_{5}\right)$ in rats (25). Since AG1296 is a compound which has been used for in vitro experiments, molecular targeted drugs which have been developed for treatment of patients with malignancy should be investigated their antifibrotic effects. Among them, imatinib mesylate (previously called STI571, Gleevec in the United States and Glivec in Europe) is a potent and specific tyrosine kinase inhibitor against cabl, bcr-abl and c-kit. Imatinib has been demonstrated to be highly active in chronic myeloid leukemia (CML) and gastrointestinal stromal tumors (GIST) (26-29). The reported data regarding the specificity of imatinib for various tyrosine kinases shows that imatinib also specifically inhibits PDGFR tyrosine kinase (30). Therefore, we and others have tried to demonstrate antifibrotic effects of imatinib in various pulmonary fibrosis models. As shown in figure 3 , imatinib strongly inhibited the fibrogenesis in the lungs treated with bleomycin via inhibiting the growth of mesenchymal cells in vivo in mice (31). Daniels $e t$ al. reported that imatinib could inhibit the activity of TGF- $\beta$ via inhibiting c-Abl kinase in addition to the blocking of PDGFR signaling (32). They also demonstrated that imatinib prevented bleomycin-induced pulmonary fibrosis in mice. Furthermore, Abdollahi et al. demonstrated the antifibrotic effects of imatinib in murine radiation-induced lung fibrosis (33). In their experiments, they used three kinds of small molecule inhibitors, imatinib, SU9518 and SU11657, which can inhibit the common receptor PDGFR. Therefore antifibrotic effects of three inhibitors were strongly suggested to be mediated by blocking PDGFR. In addition, Yoshida et al. reported that the in vivo gene transfer of an extracellular domain of PDGFR- $\beta$ reduced bleomycin-induced pulmonary fibrosis (34). These results suggested that PDGFR is one of therapeutic target for pulmonary fibrosis.

Imatinib has also been reported to prevent fibrogenesis in the liver and kidneys (35-38). These results in addition to inhibitory effects of myelofibrosis $(39,40)$ suggest that imatinib might serve as an antifibrotic drug for various fibrotic diseases in humans.

Recently, the antifibrotic effects of other inhibitors, which could show higher activity compared to imatinib, have been reported. For example, BIBF1000 which inhibited PDGFR, VEGFR and FGFR was reported to reduce pulmonary fibrosis induced by a bleomycin in rats (41). Nilotinib was also reported to show higher antifibrotic activity as compared to imatinib (42). 


\section{A: H\&E staining}

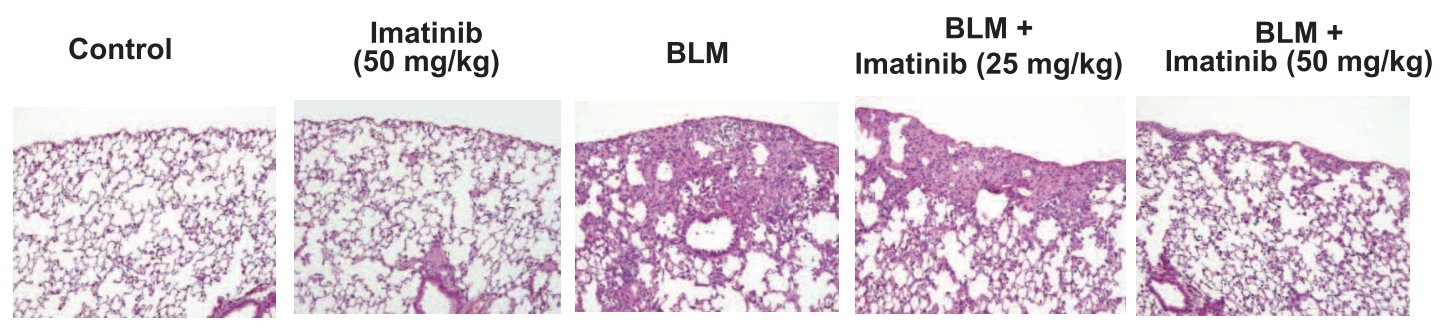

\section{B: BrdU staining}
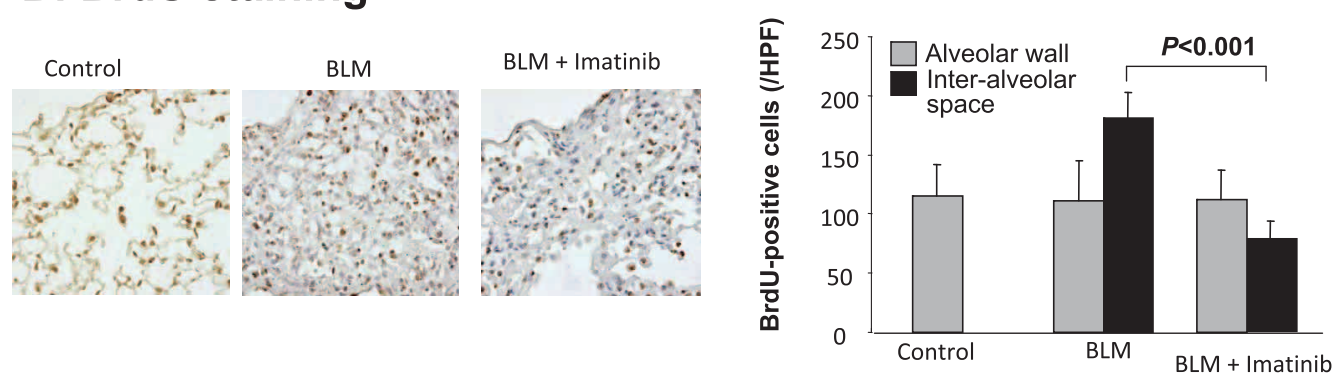

Figure 3 Antifibrotic effects of imatinib in pulmonary fibrosis induced by bleomycin in mice. Treatment with imatinib inhibited puolmonary fibrosis induced by bleomycin in a dose-dependent manner (A). The BrdU staining showed the reduced number of proliferating cells in inter-alveolar space (B). Adapted from reference 31.

\section{ANTIFIBROTIC EFFECTS OF TARGETING PDGF/PDGFR SIGNALING PATHWAY IN HUMAN}

Based on the preclinical studies, the application of imainib for treatment of patients with pulmonary fibrosis has been expected.

In the earlier experiences in clinical use of imatinib, several case reports showed the favorable activity of imatinib in patients with connective tissue diseases including systemic sclerosis (SSc) or mixed connective tissue disease (MCTD) (43-45). Chung et al. reported two cases with SSc treated with imatinib. Both patients showed the improvement of skin tightening after the use of $200 \mathrm{mg} /$ day of imatinib for three months (43). In addition, a forced vital capacity (FVC) in one patient who has lung involvement of SSc was improved from $48 \%$ of predicted to $52 \%$. Sfikakis et al. reported the severe case of SSc who have treated with $400 \mathrm{mg} /$ day imatinib for six months (44). This patient showed the improvement of FVC from $68.0 \%$ to $88.3 \%$ predicted. Distler et al. also reported the improvement of pulmonary function and HRCT findings in patients with MCTD (45). The recent phase IIa, single-arm, openlabel clinical trial with imatinib against SSc showed the efficacy in modified Rodnan skin score and FVC (46), whereas the increased adverse events were observed, and some trials were prematurely terminated for safety reasons (47).

On the other hand, the clinical trial of IPF with single dose of imatinib has been conducted and performed in USA (48). Although serious adverse events were not more common in the imatinib group, treatment with imatinib did not affect lung function such as FVC and the diffusing capacity of the lung (DLco) as well as survival of IPF patients. However, this trial has several problems in the design and results which was pointed out in the discussion of this paper and the editorial by Thannickal VJ and Roman J (49). First, this study was conducted by the anticipation of $50 \%$ incidence of achieving the primary endpoint of disease progression or death over 96 weeks of treatment, whereas the incidence in placebo group was $31.6 \%$, indicating the underpower of this study to detect the differences between groups. Second, theoretically, PDGFR are expressed not only in fibroblasts, but also in epithelial or other cells. To inhibit PDGFR signaling pathway can block the proliferation and migration of fibroblasts, but the blocking of PDGFR may affect the function of epithelial cells to prevent the fibrogenesis. In fact, Vuorinen et al. reported that PDGFR- $\beta$ are preferentially expressed in lung parenchyma, but PDGFR- $\alpha$ are strongly expressed in epithelium in addition to lung parenchyma in the lungs of IPF patient (50). 
Third, the pharmacological consideration of imatinib was also pointed out. We reported the resistance mechanism of imatinib mediated by $\alpha 1$-acid glycoprotein (AGP), which can bind to imatinib and block the effects of imatinib (51). AGP was elevated in serum of both bleomycin-treated mice and patients with IPF. Therefore, the patients enrolled in clinical trial might be better to be selected by the level of AGP. The more extensive and fine preclinical study could be required to focus the molecular target for therapeutic approach of IPF.

However, the growth factors are still in central mediators to promote pulmonary fibrosis. Recently, promising clinical trials targeting the signaling of growth factors have been reported. BIBF1120, which is derivative of BIBF1000, was reported to inhibit the progression and acute exacerbation of IPF in phase II TOMORROW study (6).

\section{FUTURE PERSPECTIVES}

The international phase III clinical trial using BIBF1120 for IPF has been in progress. BIBF1120 can inhibit VEGFR and FGFR in addition to PDGFR. The role of VEGFR and FGFR in the progression of pulmonary fibrosis is still unclear. Therefore, PDGFR still play a central role as a therapeutic target in the progression of IPF. The establishment of molecular targeting therapy against growth factors including PDGF would be expected in clinic.

\section{ACKNOWLEDGEMENT}

This work was supported by KAKENHI (18590855, 20390231 and 23659434), Grants-in-Aid for Scientific Researchs (C), (B) and a Challenging Exploratory Research, respectively, from the Ministry of Education, Culture, Sports, Science and Technology (MEXT), and a grant to the Diffuse Lung Diseases Research Group from the Ministry of Health, Labour, and Welfare of Japan.

\section{REFERENCES}

1. Gross TJ, Hunninghake GW : Idiopathic pulmonary fibrosis. N Engl J Med 345 : 517-525, 2001

2. Selman M, King TE Jr, Pardo A : Idiopathic pulmonary fibrosis : prevailing and evolving hypotheses about its pathogenesis and implications for therapy. Ann Intern Med 134 : 136151, 2001

3. American Thoracic Society : Idiopathic pulmonary fibrosis : Diagnosis and treatment. International consensus statement. Am J Respir Crit Care Med 161 : 646-664, 2000

4. Collard HR, King TE Jr: Demystifying idiopathic interstitial pneumonia. Arch Intern Med $163: 17-29,2003$

5. Raghu G, Collard HR, Egan JJ, Martinez FJ, Behr J, Brown KK, Colby TV, Cordier JF, Flaherty KR, Lasky JA, Lynch DA, Ryu JH, Swigris JJ, Wells AU, Ancochea J, Bouros D, Carvalho C, Costabel U, Ebina M, Hansell DM, Johkoh T, Kim DS, King TE Jr, Kondoh Y, Myers J, Muller NL, Nicholson AG, Richeldi L, Selman M, Dudden RF, Griss BS, Protzko SL, Schunemann HJ : An official ATS/ERS/JRS/ ALAT statement : Idiopathic pulmonary fibrosis : Evidence-based guidelines for diagnosis and management. Am J Respir Crit Care Med 183 : 788-824, 2011

6. Richeldi L, Costabel U, Selman M, Kim DS, Hansell DM, Nicholson AG, Brown KK, Flaherty KR, Noble PW, Raghu G, Brun M, Gupta A, Juhel N, Klüglich M, du Bois RM : Efficacy of a tyrosine kinase inhibitor in idiopathic pulmonary fibrosis. N Engl J Med 365 : 10791087, 2011

7. Günther A, Korfei M, Mahavadi P, von der Beck D, Ruppert C, Markart P : Unravelling the progressive pathophysiology of idiopathic pulmonary fibrosis. Eur Respir Rev $21: 152$ 160, 2012

8. Noble PW, Barkauskas CE, Jiang D : Pulmonary fibrosis : patterns and perpetrators. J Clin Invest $122: 2756-2762,2012$

9. Herdin $\mathrm{CH}$, Westermark B : Mechanism of action and in vivo role of platelet-derived growth factor. Physiol Rev 79 : 1283-1316, 1999

10. Li X, Eriksson U : Novel PDGF family members : PDGF-C and PDGF-D. Cytokine Growth Factor Rev $14: 91-98,2003$

11. Andrae J, Gallini R, Betsholtz C : Role of platelet-derived growth factors in physiology and medicine. Genes Dev 22 : 1276-1312, 2008

12. Boström H, Willetts K, Pekny M, Levéen P, Lindahl P, Hedstrand H, Pekna M, Hellström M, Gebre-Medhin S, Schalling M, Nilsson M, Kurland S, Törnell J, Heath JK, Betsholtz C : PDGF-A signaling is a critical event in lung 
alveolar myofibroblast development and alveogenesis. Cell 14 : 863-873, 1996

13. Soriano $\mathrm{P}$ : The PDGFa receptor is required for neural crest cell development and for normal patterning of the somites. Development 124 : 2691-2700, 1997

14. Levéen P, Pekny M, Gebre-Medhin S, Swolin $\mathrm{B}$, Larsson E, Betsholtz C : Mice deficient for PDGF B show renal, cardiovascular, and hematological abnormalities. Genes Dev 8 : 18751887, 1994

15. Soriano $\mathrm{P}$ : Abnormal kidney development and hematological disorders in PDGF beta-receptor mutant mice. Genes Dev 8 : 1888-1896, 1994

16. McGowan SE, Grossmann RE, Kimani PW, Holmes AJ : Platelet-derived growth factor receptor-alpha-expressing cells localize to the alveolar entry ring and have characteristics of myofibroblasts during pulmonary alveolar septal formation. Anat Rec (Hoboken) 291 : 16491661, 2008

17. Maeda A, Hiyama K, Yamakido H, Ishioka S, Yamakido $\mathrm{M}$ : Increased expression of plateletderived growth factor $\mathrm{A}$ and insulin-like growth factor-I in BAL cells during the development of bleomycin-induced pulmonary fibrosis in mice. Chest 109 : 780-786, 1996

18. Walsh J, Absher M, Kelley J : Variable expression of platelet-derived growth factor family proteins in acute lung injury. Am J Respir Cell Mol Biol 9 : 637-644, 1993

19. Zhou Y, Zheng J, Laboy M, Lasky JA : Modulation of PDGF-C and PDGF-D expression during bleomycin-induced lung fibrosis. Am J Physiol Lung Cell Mol Physiol 286 : L182-L188, 2004

20. Shimizu S, Gabazza EC, Taguchi O, Yasui H, Taguchi Y, Hayashi T, Ido M, Shimizu T, Nakagaki T, Kobayashi H, Fukudome K, Tsuneyoshi N, D'Alessandro-Gabazza CN, Izumizaki M, Iwase M, Homma I, Adachi Y, Suzuki K: Activated protein C inhibits the expression of platelet-derived growth factor in the lung. Am J Respir Crit Care Med 167 : 14161426, 2003

21. Yoshida M, Sakuma J, Hayashi S, Abe K, Saito I, Harada S, Sakatani M, Yamamoto S, Matsumoto N, Kaneda Y : A histologically distinctive interstitial pneumonia induced by overexpression of the interleukin 6, transforming growth factor beta 1, or platelet-derived growth factor B gene. Proc Natl Acad Sci USA 92 :
9570-9574, 1995

22. Antoniades HN, Bravo MA, Avila RE, Galanopoulos T, Neville-Golden J, Maxwell M, Selman M : Platelet-derived growth factor in idiopathic pulmonary fibrosis. J Clin Invest 86 : 1055-1064, 1990

23. Homma S, Nagaoka I, Abe H, Takahashi K, Seyama K, Nukiwa T, Kira S : Localization of platelet-derived growth factor and insulin-like growth factor I in the fibrotic lung. Am J Respir Crit Care Med 152 : 2084-2089, 1995

24. Gochuico BR, Avila NA, Chow CK, Novero LJ, Wu HP, Ren P, MacDonald SD, Travis WD, Stylianou MP, Rosas IO : Progressive preclinical interstitial lung disease in rheumatoid arthritis. Arch Intern Med $168:$ 159-166, 2008

25. Rice AB, Moomaw CR, Morgan DL, Bonner JC : Specific inhibitors of platelet-derived growth factor or epidermal growth factor receptor tyrosine kinase reduce pulmonary fibrosis in rats. Am J Pathol 55 : 213-221, 1999

26. Druker BJ, Talpaz M, Resta DJ, Peng B, Buchdunger E, Ford JM, Lydon NB, Kantarjian H, Capdeville R, Ohno-Jones S, Sawyers CL: Efficacy and safety of a specific inhibitor of the BCR-ABL tyrosine kinase in chronic myeloid leukemia. N Engl J Med 344 : 1031-1037, 2001

27. Druker BJ, Sawyers CL, Kantarjian H, Resta DJ, Reese SF, Ford JM, Capdeville R, Talpaz $\mathrm{M}$ : Activity of a specific inhibitor of the BCRABL tyrosine kinase in the blast crisis of chronic myeloid leukemia and acute lymphoblastic leukemia with the Philadelphia chromosome. N Engl J Med 344 : 1038-1042, 2001

28. Demetri GD, von Mehren M, Blanke CD, Van den Abbeele AD, Eisenberg B, Roberts PJ, Heinrich MC, Tuveson DA, Singer S, Janicek M, Fletcher JA, Silverman SG, Silberman SL, Capdeville R, Kiese B, Peng B, Dimitrijevic S, Druker BJ, Corless C, Fletcher CD, Joensuu $\mathrm{H}$ : Efficacy and safety of imatinib mesylate in advanced gastrointestinal stromal tumors. $\mathrm{N}$ Engl J Med 347 : 472-480, 2002

29. van Oosterom AT, Judson I, Verweij J, Stroobants S, Donato di Paola E, Dimitrijevic S, Martens M, Webb A, Sciot R, Van Glabbeke M, Silberman S, Nielsen OS : European Organisation for Research and Treatment of Cancer Soft Tissue and Bone Sarcoma Group : Safety and efficacy of imatinib (STI571) in metastatic gastrointestinal stromal tumours : a phase I study. Lancet 358 : 1421-1423, 2001 
30. Druker BJ, Tamura S, Buchdunger E, Ohno S, Segal GM, Fanning S, Zimmermann J, Lydon NB : Effects of s selective inhibitor of the abl tyrosine kinase on the growth of bcr-abl positive cells. Nature Med $2: 561-566,1996$

31. Aono $Y$, Nishioka $Y$, Inayama M, Ugai M, Kishi $\mathrm{J}$, Uehara $\mathrm{H}$, Izumi $\mathrm{K}$, Sone $\mathrm{S}$ : Imatinib as a novel antifibrotic agent in bleomycin-induced pulmonary fibrosis in mice. Am J Respir Crit Care Med 171: 1279-1285, 2005

32. Daniels CE, Wilkes MC, Edens M, Kottom TJ, Murphy SJ, Limper AH, Leof EB : Imatinib mesylate inhibits the profibrogenic activity of TGF- $\beta$ and prevents bleomycin-mediated lung fibrosis. J Clin Invest 114 : 1308-1316, 2004

33. Abdollahi A, Li M, Ping G, Plathow C, Domhan S, Kiessling F, Lee LB, McMahon G, Gröne HJ, Lipson KE, Huber PE : Inhibition of platelet-derived growth factor signaling attenuates pulmonary fibrosis. J Exp Med 201 : 925-935, 2005

34. Yoshida M, Sakuma-Mochizuki J, Abe K, Arai T, Mori M, Goya S, Matsuoka H, Hayashi S, Kaneda Y, Kishimoto T: In vivo gene transfer of an extracellular domain of platelet-derived growth factor beta receptor by the HVJliposome method ameliorates bleomycin-induced pulmonary fibrosis. Biochem Biophys Res Commun 265 : 503-508, 1999

35. Gilbert RE, Kelly DJ, McKay T, Chadban S, Hill PA, Cooper ME, Atkins RC, NikolicPaterson DJ : PDGF signal transduction inhibition ameliorates experimental mesangial proliferative glomerulonephritis. Kidney Int 59 : 1324-1332, 2001

36. Wang S, Wilkes MC, Leof EB, Hirschberg R : Imatinib mesylate blocks a non-Smad TGF- $\beta$ pathway and reduces renal fibrogenesis in vivo. FASEB J 19 : 1-11, 2005

37. Yoshiji H, Noguchi R, Kuriyama S, Ikenaka Y, Yoshii J, Yanase K, Namisaki T, Kitade M, Masaki T, Fukui H : Imatinib mesylate (STI571) attenuates liver fibrosis development in rats. Am J Physiol Gastrointest Liver Physiol 288 : G907-913, 2005

38. Neef M, Ledermann M, Saegesser H, Schneider V, Widmer N, Decosterd LA, Rochat B, Reichen $\mathrm{J}$ : Oral imatinib treatment reduces early fibrogenesis but does not prevent progression in the long term. J Hepatol 44 : 167-75, 2006

39. Beham-Schmid C, Apfelbeck U, Sill H, Tsybrovsky O, Hofler G, Haas OA, Linkesch
$\mathrm{W}$ : Treatment of chronic myelogenous leukemia with the tyrosine kinase inhibitor STI571 results in marked regression of bone marrow fibrosis. Blood 99 : 381-383, 2002

40. Klion AD, Robyn JA, Akin C, Noel P, Brown MR, Law MA, Metcalfe DD, Dunbar CE, Nutman TB : Molecular remission and reversal of myelofibrosis in response to imatinib mesylate treatment in patients with the myeloproliferative variant of hypereosinophilic syndrome. Blood 103 : 473-478, 2003

41. Chaudhary NI, Roth GJ, Hilberg F, MüllerQuernheim J, Prasse A, Zissel G, Schnapp A, Park JE : Inhibition of PDGF, VEGF and FGF signalling attenuates fibrosis. Eur Respir J 29 (5) : 976-985, 2007

42. Rhee CK, Lee SH, Yoon HK, Kim SC, Lee SY, Kwon SS, Kim YK, Kim KH, Kim TJ, Kim JW : Effect of nilotinib on bleomycin-induced acute lung injury and pulmonary fibrosis in mice. Respiration $82: 273-287,2011$

43. Chung L, Fiorentino DF, Benbarak MJ, Adler AS, Mariano MM, Paniagua RT, Milano A, Connolly MK, Ratiner BD, Wiskocil RL, Whitfield ML, Chang HY, Robinson WH : Molecular framework for response to imatinib mesylate in systemic sclerosis. Arthritis Rheum $60: 584-591,2009$

44. Sfikakis PP, Gorgoulis VG, Katsiari CG, Evangelou K, Kostopoulos C, Black CM : Imatinib for the treatment of refractory, diffuse systemic sclerosis. Rheumatology (Oxford) 47 : 735-737, 2008

45. Distler JH, Manger B, Spriewald BM, Schett G, Distler $\mathrm{O}$ : Treatment of pulmonary fibrosis for twenty weeks with imatinib mesylate in a patient with mixed connective tissue disease. Arthritis Rheum $58: 2538-42,2008$

46. Spiera RF, Gordon JK, Mersten JN, Magro CM, Mehta M, Wildman HF, Kloiber S, Kirou KA, Lyman S, Crow MK : Imatinib mesylate (Gleevec) in the treatment of diffuse cutaneous systemic sclerosis : results of a 1-year, phase IIa, single-arm, open-label clinical trial. Ann Rheum Dis 70 : 1003-1009, 2011

47. Bournia VK, Evangelou K, Sfikakis PP : Therapeutic inhibition of tyrosine kinases in systemic sclerosis : a review of published experience on the first 108 patients treated with imatinib. Semin Arthritis Rheum 42 : 377-390, 2013

48. Daniels CE, Lasky JA, Limper AH, Mieras K, Gabor E, Schroeder DR: Imatinib-IPF Study 
Investigators : Imatinib treatment for idiopathic pulmonary fibrosis : Randomized placebo-controlled trial results. Am J Respir Crit Care Med 181(6) : 604-610, 2010

49. Thannickal VJ, Roman J : Challenges in translating preclinical studies to effective drug therapies in idiopathic pulmonary fibrosis. Am J Crit Care Med 181 : 532-533, 2010

50. Vuorinen K, Ohlmeier S, Leppäranta $\mathrm{O}$, Salmenkivi K, Myllärniemi M, Kinnula VL:
Peroxiredoxin II expression and its association with oxidative stress and cell proliferation in human idiopathic pulmonary fibrosis. J Histochem Cytochem 56 : 951-959, 2008

51. Azuma M, Nishioka Y, Aono Y, Inayama M, Makino H, Kishi J, Shono M, Kinoshita K, Uehara H, Ogushi F, Izumi K, Sone S : Role of a1-acid glycoprotein in therapeutic antifibrotic effects of imatinib with macrolides in mice. Am J Respir Crit Care Med 176 : 1243-1250, 2007 